\title{
Conacher Missed the Mark on Constitutional Conventions and Fixed Election Dates
}

\section{Andrew Heard*}

Given the fundamental role that conventions play in the Canadian constitution, it is not surprising that litigants try from time to time to engage the courts in defining or even enforcing the terms of a particular convention. The Federal Court's September 2009 decision in Conacher v. Canada (Prime Minister) ${ }^{1}$ is the latest high-profile example. Duff Conacher, Coordinator of Democracy Watch, had launched a court case that challenged the 2008 federal election call as contravening either the provisions of the government's fixed-date election law (Bill C-16, ${ }^{2}$ passed in 2007), or conventions supporting the law. The Federal Court rejected Conacher's application, holding among other things that there was no constitutional convention constraining the prime minister from advising an election before the October 2009 date prescribed in the statute. Conacher's appeal was also rejected. In May 2010, the Federal Court of Appeal upheld the lower court's decision, stating that "no such convention exists" based on the evidentiary record. ${ }^{3}$ For many observers, the Conacher decision may seem unsurprising and solidly based on the existing jurisprudence dealing with constitutional conventions.

A closer examination of the Federal Court's decision, however, reveals some disturbing logic and flaws in reasoning. Some of these problems are not peculiar to the judge in the case, but flow from the positions adopted by the Supreme Court of Canada in the patriation cases. ${ }^{4} \mathrm{Co}$ nacher usefully highlights the flaws of orthodox thinking in Canadian legal circles about the nature of conventions. In particular, there are major problems with the three-part Jennings test adopted by the Supreme Court of Canada in the Patriation Reference and employed in Conacher. A fresh analysis of the issues in Conacher is needed to determine whether in fact a constitutional convention had arisen to support the fixed election date legislation.

Any pronouncement by a court of the terms of a convention can and often does amount to a political enforcement of the convention. The authority of the courts adds considerable weight to their opinions, and their conclusions are often portrayed as authoritative. Thus, it matters whether a court is correct in its assessment of the existence or terms of a convention. Unfortunately, the Jennings test can only usefully identify a subset of constitutional conventions, and it can seriously mislead analysis in other cases. The combination of problems evident in the Conacher decision raises concerns about the institutional capacity of Canadian courts to deal with constitutional conventions. Some observers might suggest that this judicial weakness could be remedied by a stricter insistence on Dicey's dictum that conventions have no place in the courtroom. ${ }^{5}$ However, as Conacher illustrates, the law is sometimes so dependent on supporting conventions that it is either unenforceable or untenable without them. In the absence of any recognized convention, the fixed election date law would appear futile.

Some laws, such as Bill C-16, are crafted with the full knowledge and intent that the bare bones of the law will be modified by support- 
ing conventions. Indeed, a number of statutes passed by the United Kingdom Parliament that now serve as Canada's bedrock constitutional documents granted personal powers to the governor general or lieutenant governors. And yet, it was understood at the time that those powers would usually be exercised according to constitutional conventions that deprive a governor of any personal choice in most circumstances. Had that understanding not existed, those statutes would have been drafted in a very different fashion. Hundreds of federal and provincial statutes providing powers to the governor in council assume that the governor will in fact neither take part in nor reject the decisions of their council. A great irony of both decisions in Conacher arises from their emphatic recognition of the conventional right of the prime minister to advise the governor general on an election, while steadfastly refusing to recognize any convention that might constrain when that election might be called.

Several interrelated problems are evident in Justice Shore's handling of conventions in Conacher. The first difficulty arises with his discussion of whether conventions must be based upon actual precedents or whether they can arise through the explicit agreement of the relevant political actors. A second flaw is apparent in his interpretation of how the Jennings test must be followed, particularly in the analysis of the views of the relevant political actors concerning a purported conventional rule. The review of the historical record that supports this analysis displays serious weaknesses. These related problems may well have led to an erroneous conclusion about the existence of a constitutional convention in this case.

\section{The Creation of Conventions by Explicit Undertakings}

The application filed on Duff Conacher's behalf argued that a constitutional convention had arisen to preclude the prime minister from advising the election in 2008, a year in advance of the date ostensibly set in Bill C-16's amendments to the Canada Elections Act. ${ }^{6}$ In essence, Conacher's counsel argued that various gov- ernment statements, given during Parliament's consideration of Bill C-16, amount to an explicit undertaking that elections would henceforth be held on fixed election dates unless the government of the day lost the confidence of the House of Commons. Expert testimony from Peter Russell argued that conventions could arise through such undertakings, becoming established without the need for an actual precedent beforehand. Justice Shore considered the argument by Conacher's counsel - previously asserted in my own book ${ }^{7}$ - that conventions could arise in this way. However, the judge rejected all of these points, holding that the legislative record was not consistent and that, in any case, constitutional conventions could not arise in a domestic setting through explicit undertakings. Although Justice Shore noted that Peter Hogg had also recognized that conventions could arise through explicit agreement, he took solace in a footnote that appeared in Hogg's text. He noted, on the authority of this footnote, that R.T.E. Latham had written in 1949 of his belief that the only examples of conventions arising through agreement were to be found in the context of Commonwealth relations. ${ }^{8}$ The trial judge embraced Latham's objection that domestic political actors could not create conventions by agreement, because they could not bind their successors to those commitments; by contrast in the international context, it is accepted that governments can and do bind their successors.

Justice Shore's stance on these points does not survive close scrutiny. First of all, the supposed problem of actors not being able to bind their successors in the domestic context is at best something of a red herring and at worst illogical. If one considers the context of traditional conventions that arise through historical precedent, there is the inescapable assumption that future actors are bound by the views of their predecessors. One must rely on statements by the relevant political actors in historical precedents that they believed themselves to be bound by a rule in order for a convention to be recognized under the Jennings test. Many years can separate the historical events from the current situation, and yet it is accepted that presentday actors are obliged to follow the precedents set in the past. Indeed, when the Supreme Court 
of Canada declared in the Patriation Reference that there was a convention requiring substantial provincial consent to constitutional amendments affecting provincial powers, the majority decision only explicitly considered the precedents and statements involving political actors who had long left the stage, or even died. And yet, the Court held that this convention continued to exist, and as a consequence it bound the current government.

Secondly, there are a range of examples of constitutional conventions arising through the explicit undertakings of the relevant actors. As Justice Shore noted, the most widely cited examples of these types of conventions arose during the Imperial Conferences in the 1920s and 1930s, in which the British and Dominion governments agreed to a series of changes in their relationships. These were considered as binding rules right from the time of the agreements. However, there are examples of domestic conventions as well. For example, the first ministers agreed in 1987 that the prime minister would only appoint senators from lists of nominees submitted by provincial premiers until the Meech Lake Accord was formally ratified: "Until the proposed amendment relating to the appointments to the Senate comes into force, any person summoned to fill a vacancy in the Senate shall be chosen from among persons whose names have been submitted by the Government of the province to which the vacancy relates and must be acceptable to the Queen's Privy Council for Canada." "This was the practice until the death of the Accord in 1990. Another example of conventions arising through explicit undertakings can be found in the commitments made by the premiers of Nova Scotia and New Brunswick that they would not allow Prince Edward Island to be isolated in any proceedings under the regional veto formula enacted in the Constitutional Amendments Act ${ }^{10}$ of 1996. More recently, one could view as constitutional conventions the undertakings of Prime Minister Harper's most recent Senate appointees that they would resign within eight years of their appointment, to honour the spirit of the government's legislative proposals to limit the tenure of future senators. This informal obligation, binding the actors in ways that transform the legal framework, seems to qualify as a constitutional convention. Furthermore, British scholars argue that conventions can be created by unilateral declarations, such as when prime ministers impose limits on how cabinet colleagues exercise their legal powers. ${ }^{11}$ These unilateral undertakings can create conventions which bind that actor and even others over whom he or she has some power of enforcement.

Critics of this view might object that none of these examples of purported conventions created by agreement or declaration should really be recognized as conventions until some precedent demonstrates that the actors are indeed observing a binding rule. But such an objection should also logically be applied to any convention established by precedent. One should equally say that we cannot know if there is still any convention until current actors articulate a sense of obligation and actually confirm their obedience to the rule by demonstrably following it in relevant circumstances. Indeed, sceptics of conventions argue that they should not be considered rules, because in the final analysis political actors are free to break with tradition and amend, ignore, or destroy any convention at any time; they simply have to get away with their new behaviour. ${ }^{12}$

These general objections, however, seem to degenerate into reductio ad absurdum and provide as little analytical guidance as objections that there can be no enduring law because what is "law" can be changed at any moment by the courts, legislature, or executive. The reality with both conventions and law is that there is a palpable and enduring acceptance of a range of rules; these rules may change or be extinguished, but until then they are considered binding and generally observed by most actors most of the time.

\section{The Jennings Test}

Fundamental flaws in how the Federal Court's Conacher decision treats the convention question stem from following what might now be called the orthodox view of conventions in Canada, given a stamp of approval by the Supreme Court of Canada when it considered constitutional conventions in the Patriation Refer- 
ence. The majority of the Court in that reference case adopted Sir Ivor Jennings's suggestions for identifying whether a convention exists:

\begin{abstract}
We have to ask ourselves three questions: first, what are the precedents; secondly, did the actors in the precedents believe that they were bound by a rule; and thirdly, is there a reason for the rule? A single precedent with a good reason may be enough to establish the rule. A whole string of precedents without such a reason will be of no avail, unless it is perfectly certain that the persons concerned regarded them as bound by it. ${ }^{13}$
\end{abstract}

Implicit in the Jennings approach is the belief that a convention cannot be established without a clear historical precedent. So, in Conacher, Justice Shore appears at first glance to be on firm ground in declaring that there could be no convention restraining the timing of elections: "The three questions test fails because there are no precedents in this regard from the relevant actors." 14

Unfortunately, neither Jennings nor the Supreme Court provided any useful guidelines as to how to make this test work. Major problems arise from trying to rely definitively on either historical precedents or statements by political actors. It is essential to explore these problems in depth, because they may prove insurmountable in many situations. If the Jennings test is flawed, then judges should be aware of the flaws before placing too much faith in it. And there do appear to be serious weaknesses in both the heavy reliance on precedents and the narrow approach to examining the actors' beliefs. A review of these problems can usefully lay the foundation for a reassessment of the conventions question put to the court in Conacher.

A reliance on historical precedents is a bit like trying to navigate by the stars. It is all well and good in a clear sky, but the heavens are not always obliging. The sky may be entirely clouded over, or large patches of the sky may be covered. Similarly, political precedents work wonderfully when they exist and when one can tell which precedents are relevant to our constitutional navigation. But historical precedents can be completely missing, date from a bygone era, or contradict one another. And as already noted, some constitutional conventions exist as binding rules even before a precedent has occurred. Another issue is whether one considers both positive and negative precedents. Sometimes, what did not happen and why can be just as revealing, or even more so, than what has happened. Furthermore, an actor's breach of an apparent conventional obligation need not be evidence that the rule has ended or never existed, as the public reaction can be enough to reinforce that obligation; at times, the exception can indeed prove the rule. It is, therefore, quite erroneous to conclude that the absence of a clear line of consistent precedents demonstrates that political actors are not bound by convention.

Precedents can provide useful insights in the identification of conventions, but their importance should be viewed in perspective. Precedents can be informative and illustrative of past political practices. At times there are clear chains of events that can be discerned, and those precedents add weight to the identification of conventions. However, one must keep in mind the passage of time and any shifts in political values that have occurred over the course of any set of precedents, and particularly since the last precedent. The reactions of the attentive public are also important in the historical events surveyed. As will be discussed below, the opinions and beliefs relevant to the identification of conventions cannot be limited to the prime political actors involved.

Relying on precedents can be problematic in the great many contexts where precedents are few and far between or not publicly revealed. For example, there are certain challenges in dealing with the relationships between the Canadian governors and their first ministers. Most of what transpires is strictly confidential, leaving us with a very incomplete picture of what transpires; only occasionally are glimpses provided in memoirs. Until recently, for example, commentators had to reach back to 1926 and 1896 for examples of a governor general refusing the advice of a prime minister. However, Adrienne Clarkson's memoirs reveal an occasion where she refused Paul Martin's advice to hold his swearing-in ceremony on Parliament Hill. The governor general refused on the grounds that 
this would have imposed an American presidential element, which she believed to be entirely inappropriate in a parliamentary system. ${ }^{15}$ If Clarkson had not revealed this, we would still be left believing that the last instance of refused advice was in 1926. Similarly, there has been little general public knowledge of the occasions on which lieutenant governors have refused advice. The published accounts of a refused election call in Newfoundland ${ }^{16}$ in 1972 and of an Albertan order in council ${ }^{17}$ in 1993 (authorizing a financial grant to an individual) leave one wondering what else may be occurring behind the scenes that never sees the light of day.

Nevertheless, precedents can be particularly helpful in cases where there is little or no commentary by relevant actors or scholars on possible rules and obligations. For example, there is undoubtedly a constitutional convention that the governor general issues the separate proclamations for the dissolution of Parliament and for the issuance of election writs at the same time. However, this convention would fail the Jennings test, as there do not appear to be any substantive public comments on the necessity for the governor general to issue these proclamations together. Indeed, there has been little public awareness until recently that these are separate actions. And yet, this practice is much more than a simple habit or custom. When combined with the practical and constitutional reasons for a rule, a string of precedents can help cement a practice into a binding convention.

The Jennings test really only works for a subset of conventions which arise from political practice and develop into convention. And even then, this test can only easily identify conventions with a clear string of consistent precedents that reach into the contemporary era. If one were able to draw only from century-old precedents, for example, one might well end up simply trying to resurrect long-lapsed rules that are no longer supported. While a number of conventions can be categorized through this test, others cannot because of unclear, contradictory, or antiquated precedents. And conventions can and do arise without any historical precedent, through express agreement among all the relevant actors or unilateral declaration by someone (such as the prime minister) in a position to enforce them. While precedents can offer important insights into identifying conventions, in the end they may be too problematic to be either determinative or essential to a convention.

Even so, Justice Shore may have been mistaken to assert that there were no relevant precedents that related to the federal fixed-date election legislation. Precedents from provincial jurisdictions can also be relevant for constitutional conventions that relate to similar situations at the federal level. When dealing with conventions at the national level, constitutional scholars and actors alike refer to provincial precedents relating to the governors' prerogative powers, the details of the confidence convention, or other aspects of responsible government; federal precedents are also frequently cited in provincial politics. Where the principles and details are similar, precedents from the other level of government are highly instructive and widely relied upon. It is, therefore, only logical to look to provincial precedents when examining the operation of federal legislation, such as Bill C-16, that was explicitly drafted according to the existing provincial models. Furthermore, the conventions relating to the calling of an election that would potentially be modified by the new legislation are essentially identical at the federal and provincial levels in Canada. When Bill C-16 passed through Parliament, similar legislation was to be found in five provinces and the Northwest Territories; since that time, two more provinces have enacted fixed election date legislation. By the time of the 2008 election call, there had already been five provincial or territorial elections held in keeping with a legislated rotation of elections every four years. British Columbia held an election on May 17, 2005, the Northwest Territories on October 1, 2007, Ontario on October 4, 2007, and Newfoundland on October 9, 2007. In addition, Prince Edward Island held an election on May 18, 2007 in keeping with the future four-year limit included in legislation passed just three days before the election call. ${ }^{18}$ While these five precedents may not be determinative, they do demonstrate that all other Canadian governments considered themselves bound by their 
four-year election cycles. They reveal a strong consensus that where fixed election date laws exist, they must be respected. ${ }^{19}$

The second part of the Jennings test is equally problematic in its operation, and its application in Conacher no less flawed. A serious practical hurdle is the simple fact that political actors are not obliging enough to provide clear or forthright public statements about many of the conventions they consider themselves bound by. It is just impractical to require clear statements as a necessary requirement for determining every convention, because the search will often be futile. For example, Prime Minister Harper does not appear to have made any clear declarations about the conventions concerning the appointment of the governor general when he advised the Queen to appoint David Johnston as the new governor general in 2010, even though he set up an independent advisory committee to propose a non-partisan nominee. Jennings himself conceded that this part of the test may not be necessary when he asserted, "A single precedent with a good reason may be enough to establish the rule." 20

There is also a temptation to take Jennings's words too literally, that all one should be concerned with are the views of the actors directly involved in an historical precedent. The Supreme Court of Canada's examination of the conventions in the 1981 Patriation Reference was seriously weakened by not including any statements by cabinet ministers later than 1965. This omission was all the more curious since the 1971 Victoria Charter was negotiated with the explicit understanding that the agreement of every province was necessary to its enactment; and it failed once Quebec rescinded its support. As well, the Court did not bother to assess the views of provincial premiers, which is curious considering the convention in question related to amendments to provincial powers. The views of a range of political leaders across time can be equally, and often more, informative than focusing simply on precedents plucked here and there from their full context.

Justice Shore also took this part of the test literally when he concluded that the only relevant actors in dissolution are the governor gen- eral and the prime minister. This is problematic from the start since governors general in Canada are precluded from speaking publicly about the exercise of their prerogative powers. But having identified only two relevant actors, Shore then went on to base his judgment not on statements by Stephen Harper, but on statements by Rob Nicholson, the cabinet minister who sponsored Bill C-16. ${ }^{21}$ Shore also approached the identification of statements as if identifying conventions involved the same process as statutory interpretation. He limited his examination to statements contained in Hansard and in transcripts of parliamentary committee hearings. However, one cannot restrict one's examination to the legislative record followed in statutory interpretation. Constitutional conventions are political rules and the political arena in which they are discussed is vast. Political figures give vital statements of their views in myriad settings beyond parliamentary precincts. In principle and practice, one cannot restrict this analysis to the legislative record.

The views of the most relevant political actors can be sufficient to determine a convention where the statements are clear and supported by principle. For example, the creation of conventions through express agreement or declaration relies upon the combination of a commitment to the new rule and a sound constitutional reason for the rule. However, such statements cannot always be relied upon to determine the existence of a convention, because they may be missing, contradictory, or deliberately misleading. In the case of the governor general, prevailing customs actually prevent incumbents from publicly discussing their reasons for exercising their reserve powers in a particular way.

\section{Conventions as Rules of Critical Morality}

On a broader perspective, the second part of the Jennings test promotes an untenable view of constitutional conventions as rules dependent upon the internal morality of specific political actors. One of the most often quoted definitions of constitutional conventions is offered by $\mathrm{O}$. Hood Phillips; he said they are "rules of politi- 
cal practice which are regarded as binding by those to whom they apply." ${ }^{22}$ At one level, this is a sensible notion. Political actors cannot be bound by rules in the absence on an obligation. Certainly if none of the actors believe a convention exists, it is hard to argue from any perspective that one does. But as F.F. Ridley points out, if a convention must be something that the political actors feel obliged by, then they are freed from that obligation at any time they no longer feel it. Indeed, he objected to Hood Phillips's definition as a tautology: "Conventions are considered binding as long as they are considered binding." ${ }^{3}$

Conventions must be much more than rules of internal morality if they are to operate as constitutional rules at all. The reliance on the internal sense of obligation opens the door to tremendous abuse and damage by the deliberately deceptive and the innocently ignorant. But in reality our political system does not operate in the vacuum of our political leaders' internal morality. Despite the determination of Canadian judges to adhere to the literal wording of Jennings's test and only concern themselves with the beliefs of actors in specific historical precedents, our constitutional discourse is very much richer. And the discussion and portrayal of the obligations facing our political actors is very much a product of this community discussion. The views of constitutional experts, think tank analysts, and leading journalists not only fill the airwaves and print columns, but the former in particular are routinely consulted and quoted by politicians in their own assessment of whether a convention exists. Legislative committees often invite scholars and other experts to give their perspectives on particular conventions and constitutional obligations. Thus, the views of key political actors may at times be crucial, but the purported views of any one actor may at times be outweighed by the consensus of the broader political community.

Jennings's own concession that conventions might arise through a single precedent with "a good reason" for the rule points to the important role of the larger constitutional community. Jennings does not elaborate on who decides whether there is a good enough reason for the rule. But that determination must in practice be the prevailing view of the engaged community.

The literal view of the Jennings test adopted in Conacher wrongly implies that conventions are rules of internal morality, and thus holds them hostage to the personal whims, ignorance, or connivance of individual political actors. However, most constitutional conventions operate in reality as a system of critical morality, with the preponderant views of the larger constitutional community framing moral obligations on the current political actors. ${ }^{24}$ An important step in understanding conventions better can come from moving beyond the Hood Phillips notion of conventions as rules considered binding by those to whom they apply. As Geoffrey Marshall writes, "It would seem better to define conventions as the rules of behaviour that ought to be regarded as binding by those concerned in working the constitution when they have correctly interpreted the precedents and the relevant constitutional principles." 25 And Bradley and Ewing underscore that conventions are best viewed as prescriptive rules and not just descriptions. ${ }^{26}$ Implicit in these views is the notion that there is a standard of behaviour that in some sense must be independent from the actual beliefs of the political actors in a given situation. Jeremy Waldron made this point quite explicitly when he wrote about conventions: "They are normative. They are used for saying what ought to be done, and ... they are used as a basis for criticism if someone's behaviour does not live up to them. We use them to judge behaviour, not merely to predict it." ${ }^{27}$

\section{The Evidence for a Convention Respecting Fixed Election Dates}

The question then becomes whether there was a general expectation that the prime minister would be obliged to respect the spirit of the legislation. There are a number of components to the analysis required to answer this question. The first is the understanding of the legislators who debated and passed Bill C-16. Important evidence for this understanding can be found in the specific statements given by the prime 
minister and other government spokespersons regarding this legislation. Also relevant is the behaviour of the government between the passage of C-16 and the 2008 election, as well as the public discussion of perceived constraints on the government.

Very clear messages were in fact given by the prime minister and other members of cabinet about both the need for, and the intended effects of, fixed election date legislation. Four days before Bill C-16 was introduced into the Commons, Prime Minster Harper gave a speech in Victoria in which he announced the intention to legislate fixed elections dates:

\begin{abstract}
First, we will introduce a bill calling for fixed election dates, at the federal level. As you know, BC - as well as Ontario, Newfoundland and Labrador - has gone this route. Fixed election dates would prevent governments from calling snap elections for short-term political advantage. They level the playing field for all parties. The rules are clear to everyone. In the case of our proposal, we will be asking for fixed election dates every four years, with the first vote set for the fall of 2009. Of course, such legislation always requires respect for confidence votes. So the will of the majority in Parliament always prevails. But fixed election dates stop leaders from trying to manipulate the calendar simply for partisan political advantage. Now I know the polls say, if an election were held now, we'd win a majority. But the polls also say that no one wants an unnecessary election. So unless we're defeated or prevented from governing, we want to keep moving forward and to make this minority Parliament work over the next three years. ${ }^{28}$
\end{abstract}

After that speech, Harper is quoted as telling reporters, "The only way we can have justice is to have a fixed election date, because an election without a fixed election date is a tremendous advantage for the party in power." ${ }^{29} \mathrm{On}$ the day the government introduced Bill C-16 into the House of Commons, Harper was asked about the possibility of an early election call. He replied:

Mr. Speaker, the government is clear that it will not be seeking an early election. At any time Parliament can defeat the government and provoke an early election, if that is what the opposition irresponsibly chooses to do.... We brought in legislation, modelled on those of the provinces, to set elections every four years and set the next election for October 2009. ${ }^{30}$

Shortly after the introduction of Bill C-16, Government Whip Jay Hill is reported to have said:

I think it's an important step and sends a signal to Canadian people that this Prime Minister and this government are willing to give up that power of having the authority to call an election when he sees fit. He's willing to turn that over to the Canadian people in the sense of having a law on the book that mandates when the next election will be, of course, other than the possibility of being defeated. ${ }^{31}$

On several occasions the minister principally responsible for the bill, Rob Nicholson, underlined a number of important statements about the purpose behind and operation of the bill. Nicholson's speech at third reading clearly detailed the intention to eliminate the prime minister's ability to call elections simply for partisan advantage:

All parties agree with the principle that the timing of elections should not be left to the Prime Minister, but should be set in advance so all Canadians know when the next election will occur.... What we have is a situation where the Prime Minister is able to choose the date of the general election, not based necessarily on what is in the best interests of the country, but what is in the best interests of his or her political party. Bill C-16 would address this problem and would produce a number of other benefits. $^{32}$

And on the day that Parliament finally passed Bill C-16 the new minister in charge of the legislation, Peter Van Loan, said, "This important piece of legislation will ensure fairness in the electoral process by eliminating the power of the governing party to call an election to capitalize on favourable political circumstances." ${ }^{33}$

The only exception to the legislation's schedule of fixed election dates that government leaders emphasized in debate involved occasions when a government loses the confidence of the House. As Nicholson told the House, "In particular, the Prime Minister's prerogative to 
advise the Governor General on the dissolution of Parliament is retained to allow him or her to advise dissolution in the event of a loss of confidence." ${ }^{34}$ As noted earlier, however, Prime Minister Harper had also alluded to a second possible justification for an early election, if the government was "prevented from governing."

The government statements announcing Bill C-16's introduction, and during Parliament's consideration of the measure, are very clear and consistent in several respects. These common messages include the recognition that the pre-existing prime ministerial discretion was unfair, and that the new legislation would put an end to that situation. The new norm would be elections held at fixed dates. There was a recognition that this fixed schedule could not necessarily apply to a minority government. The principal exception related to the defeat of a government on a matter of confidence. The other possible exception, vaguely alluded to, would arise if a government was "prevented from governing," implicitly through some parliamentary stalemate.

Constitutional scholars, government lawyers, and party officials who appeared before the Commons and Senate committees that reviewed Bill C-16 consistently voiced a view that the measure would not provide legal constraints on the prime minister's ability to request and secure an election whenever he wished. But most did also indicate that the passage of such legislation would significantly change expectations of government behaviour and lead to an informal obligation to respect the fixed election schedule. Michael Donison, then executive director of the Conservative Party, told the Commons committee, "This is really a relinquishment, a voluntary relinquishment of prime ministerial discretionary power when it comes to calling an election.... What fixed date elections do is create the expectation in the political classes and in the citizenry that this is the new norm, the new standard." ${ }^{35}$ Department of Justice lawyer Warren Newman also testified, "[T]his legislation contains a directive to officials, to the public at large, and to all those associated with the elections process that there will be an election on this date." ${ }^{36}$ And as Patrick Monahan concluded:

[T] he practical effect of this is to say that the previous situation is no longer acceptable. It will no longer be acceptable for the Prime Minister, virtually at any time but effectively two or three years after a previous election, to simply say, "We will now have an election because I think I can win.” The presumption is that the election will be held in the fourth year... It will very quickly become the custom and the accepted practice. ${ }^{37}$

After the enactment of Bill C-16 into law, there followed a period of over a year in which the government consistently indicated that the timing of the next election depended entirely upon whether the opposition decided to defeat it on a matter of confidence. The media commentary also consistently worked with the assumption that an election would only come if the government was defeated. There was speculation that the government was trying to manoeuvre the opposition into defeating it on a matter of confidence, consistent with the belief that an election would only come on a lost confidence vote.

A selection of comments by media commentators can convey the tone of discussions in this period. Alexander Panetta wrote, "Unless Harper turned his back on his promise of fixed election dates and unilaterally went to the Governor General seeking a fresh mandate, there could only be an election if all three opposition parties combined to vote down the minority Conservative government." ${ }^{38}$ John Ivison mused, "The passage of the fixed-elections legislation means that the next general election will take place in October, 2009, unless all three opposition parties combine to bring down the Harper government. Since none are yet ready to fight an election, Mr. Harper can plan for another two years in office with some confidence." 39 And Don Martin said, "Mr. Harper is handcuffed by his self-designated fixed election date in October, 2009, so he needs three willing partners to lose the confidence of Parliament and theoretically win big in an election." ${ }^{30}$ Norman Spector's views are encapsulated in the following: "As Prime Minister, Stephen Harper's second-biggest mistake was to legislate fixed election dates, thereby transferring the power 
to call an election before October of next year to the opposition parties." ${ }^{31}$ Even Tom Flanagan, Harper's former chief of staff, wrote:

Before the passage of C-16, a prime minister could have responded by declaring gridlock and asking for an election. Even a behind-thescenes threat to that effect would have probably sobered up the opposition parties because none actually want an election right now. But with C-16 in place, the government may have to resort to different tactics, declaring highpriority bills to be matters of confidence and daring the opposition to defeat them. ${ }^{42}$

More than a year after the enactment of the fixed-date legislation, Ian MacDonald believed that the prime minister no longer had the personal discretion to call an early election:

\begin{abstract}
The Harper Conservatives, like the Pearson Liberals in 1965, are tired of a minority House, and itching to go to the polls. But by introducing a fixed election date of October 2009, Harper has denied himself a prime minister's greatest advantage of incumbency - the power of dissolving the House whenever he thinks it's a nice day for an election. He thought it was the right thing to do. Go figure. As a result, he must await his government's demise, or somehow engineer his defeat in the House. ${ }^{43}$
\end{abstract}

From the brief review of a range of political commentators, it is clear that a general belief had developed that the fixed date legislation created a new set of obligations concerning when and how elections should be called.

With this review in hand, of the history of the fixed-date election legislation and the events leading up to the 2008 election, one can reach some clearer conclusions as to whether there was indeed a constitutional convention constraining the prime minister from calling an early election. Numerous statements by the prime minister, cabinet ministers, and the executive director of the party consistently reinforced the notion that this legislation meant an end to the prime minister's discretion to call early elections. There was a commitment to a new norm of scheduled election dates. The only exceptions would be if a government lost a vote of confidence or somehow was prevented from governing. Far from being ambiguous, as Jus- tice Shore would have it, the record is very clear and consistent on this commitment. The commitment was sufficiently clear and widely understood that for over a year after the enactment of this legislation, media commentary and government statements assumed that an early election could only come about if the government was defeated on a test of confidence. The provincial and territorial precedents of elections held on their legislated dates further reinforced the consensus that the prime minister was under an obligation not to call an early election unless defeated or stalemated. Those provincial precedents and the adoption of fixed election date legislation in seven provinces provide good evidence of the broadly held belief in the need to respect fixed election dates.

\section{Conclusion}

It is accepted by modern British and Canadian scholars who have made any significant study of the matter that conventions can be created through undertakings by the relevant actors. And there is considerable evidence that such an understanding was indeed given. In light of the repeated commitments made by leading government actors and the general acceptance of those commitments as binding, it appears that a constitutional convention had indeed been created.

The reaction of the informed public to the early election call adds further weight to the conclusion that a convention did - and continues to - exist. In the run-up to the actual election call, the government had started to spin the obligation under the legislation as only necessarily applying to majority governments. And it argued that the House of Commons had become dysfunctional, and that meetings between the prime minister and the opposition leaders failed to secure any commitment from them to allow Parliament to continue to operate until the scheduled election. Far from saying that the prime minister was under no obligation at all to respect the fixed date legislation, government statements seemed to be at pains to reconcile the need for an early election with the legislation. The generally negative media reaction to the early election call also reinforced the belief 
that the prime minister was evading a clear duty, even if there was a legal loophole he could exploit.

In conclusion, it does appear that the prime minister broke a convention in securing an early election. The reasoning on this question in Conacher is deeply flawed. The judge was simply wrong in asserting that conventions cannot exist in the absence of precedents. The heavy reliance on the Jennings test reveals a serious deficiency in the judicial approach to conventions. That test has not been widely adopted elsewhere; indeed, it has not been embraced by modern British scholars precisely because of its weaknesses. The Jennings test may seem like an attractive tool to some, but it is a very unreliable one for identifying political rules like conventions. While it has its uses in helping to identify a subset of conventions, there are too simply many problems to apply it rigorously. Its supporters claim that it provides a rigorous test for identifying conventions, but it is simply impractical to apply this test consistently. The Jennings test is also based upon flawed views of the nature and genesis of conventions that, when applied literally, relegate conventions to being weak rules of internal morality. In any event, the Conacher decision is also factually mistaken in its insistence that the public record was ambiguous. Commitments were clearly and consistently given. These commitments underscored that the government could no longer advise an early election simply for its own advantage, and it could only advise an early election if it lost a vote of confidence or was rendered incapable of governing for some other reason. This commitment was widely accepted and structured public discourse after the enactment of the legislation. It also framed a negative reaction to the early election call in 2008. Far from demonstrating that no convention constrained the prime minister, a full analysis of the enactment of Bill C-16 and of the events leading up to the 2008 election reveals the prime minister's actions to be a breach of a clear conventional obligation.

\section{Notes}

Associate Professor, Department of Political Science, Simon Fraser University 2009 FC 920 [“Conacher (FC)”]. Bill C-16, An Act to amend the Canada Elections Act, 1st Sess., 38th Parl., 2007 (assented to 3 May 2007).

3 Conacher v. Canada (Prime Minister), 2010 FCA 131 at para. 12 (CanLII). Democracy Watch immediately announced its intention to seek leave to appeal the decision to the Supreme Court of Canada. See: Democracy Watch, News Release, "Federal Court of Appeal Ruling Means Harper Conservatives Broke Their 2006 Election Promise to Fix Election Dates" (26 May 2010), online: Democracy Watch <http://www.dwatch.ca/camp/ RelsMay2610.html>. Given the brevity of the appeal decision, this paper will focus principally on the lower court's decision.

4 Reference re Resolution to Amend the Constitution, 1981 CanLII 25 (S.C.C.), [1981] 1 S.C.R. 753 [Patriation Reference]; Reference re Objection by Quebec to a Resolution to Amend the Constitution, 1982 CanLII 219 (S.C.C.), [1982] 2 S.C.R. 793.

5 A.V. Dicey, An Introduction to the Study of the Law of the Constitution, 8th ed. (London: Macmillan, 1924) at 30-31.

6 S.C. 2000, c. 9.

7 Andrew Heard, Canadian Constitutional Conventions: The Marriage of Law and Politics (Toronto: Oxford University Press, 1991) at 10-14.

8 Conacher (FC), supra note 1 at para. 45, citing R.T.E. Latham, The Law and the Commonwealth (Oxford: Oxford University Press, 1949) at 610.

91987 Constitutional Accord ("The Meech Lake Accord"), s. 4, online: Solon.org <http://www. solon.org/Constitutions/Canada/English/Proposals/MeechLake.html>.

10 S.C. 1996, c. 1.

11 S.A. de Smith, Constitutional and Administrative Law, 2nd. ed. (Harmondsworth: Penguin, 1973) at 60 .

12 F.F. Ridley argues that conventions should rather be thought of as "maxims or precepts": "There is No British Constitution: A Dangerous Case of the Emperor's Clothes" (1988) 41 Parliamentary Affairs 340 at 358.

13 Sir Ivor Jennings, The Law and the Constitution, 5th ed. (London: University of London Press, 1959) at 136.

14 Conacher (FC), supra note 1 at para. 46.

15 Adrienne Clarkson, Heart Matters (Toronto: Viking, 2006) at 195.

16 Edward Roberts, "Ensuring Constitutional Wisdom During Unconventional Times” (2009) 32:1 
Canadian Parliamentary Review 13 at 16.

17 Joan Crockatt, "Lt.-Gov. Wouldn't OK Grant from Kowalski” Edmonton Journal (23 December 1994) A1.

18 The P.E.I. precedent is all the more instructive since Bill 38 had originally stipulated that an election must be held by May 2008, and thereafter every four years. The 2008 date marked the maximum five year life allowed under the Constitution. Instead, the premier called the 2007 election at the four-year mark.

19 Since the 2008 federal election there has been a second provincial election in B.C. (2010), held according to the fixed election date legislation.

20 Jennings, supra note 13 at 136.

21 Conacher (FC), supra note 1 at paras. 47, 56.

22 O. Hood Phillips, Constitutional and Administrative Law, 5th ed. (London: Sweet \& Maxwell, 1973) at 77.

23 Ridley, supra note 12 at 358.

24 For a contrary view, that conventions struggle to operate as rules of critical morality, see Joseph Jaconelli, “The Nature of Constitutional Convention" (1999) 19 Legal Studies 24 at 42-45.

25 Geoffrey Marshall, "What Are Constitutional Conventions?” (1985) 38 Parliamentary Affairs at 39.

26 A.W. Bradley and K.D. Ewing, Constitutional and Administrative Law, 14th ed. (London: Pearson, 2007) at 20.

27 Jeremy Waldron, The Law (London: Routledge, 1990) at 62.

28 Stephen Harper, "An address by the Prime Minister on democratic reform" (26 May 2006), online: Prime Minister of Canada <http://www. pm.gc.ca/eng/media.asp?id=1183>.

29 "Harper Wants Fixed Dates for Federal Elections" CTV News (27 May 2006), online: CTV. ca $<$ http://calgary.ctv.ca/servlet/an/plocal/ CTVNews/20060526/harper_fixed_elexns_0605 26/20060527/?hub=EdmontonHome $>$.

30 House of Commons Debates, No. 029 (30 May 2006) at 1722.

31 Bea Vongdouangchanh, "Conservatives say fixeddate elections 'just one step" "The Hill Times (12 June 2006) 23.

32 House of Commons Debates, No. 077 (6 November 2006) at 4729.

33 Privy Council Office, News Release, "Canada's New Government Delivers on Fixed Date Elections" (3 May 2007).

34 House of Commons Debates, No. 077 (6 November 2009) at 4730.

35 House of Commons Standing Committee on Procedure and House Affairs, Evidence, 39th
Parl., 1st sess., No. 020 (3 October 2006) at 2, 10.

36 House of Commons Standing Committee on Procedure and House Affairs, Evidence, 39th Parl., 1st sess., No. 018 (26 September 2006) at 6.

37 Standing Senate Committee on Legal and Constitutional Affairs, Proceedings, 39th Parl., 1st sess., Issue 21 (15 February 2007) at 48, 53.

38 Alexander Panetta, Telegraph Journal (17 March 2007) A5.

39 John Ivison, "Do the shuffle" National Post (11 August 2007) A5.

40 Don Martin, "Dion left with two bad options" National Post (4 October 2007), online: NationalPost.com < http://www.financialpost.com/ scripts/story.html?id=b7ada19c-c364-4099-a012b8aa606c5b87\&k=51765>.

41 Norman Spector, "The haunting of Harper: fixed date, public inquiry" The Globe and Mail (3 January 2008), online: GlobeandMail.com < http:// www.theglobeandmail.com/news/opinions/ article658506.ece>.

42 Tom Flanagan, "It's Time for Conservative Minority Brinkmanship" The Globe and Mail (1 August 2007) A15.

43 L. Ian MacDonald, "The Harper minority appears to have run its course" Montreal Gazette (28 July 28, 2008), online: Canada.com <http://www. canada.com/story_print.html?id=3b73ea2f-2cb34ff6-983c-599fb6452c10\&sponsor $=>$. 